\title{
Characterization of Resistance to Stripe Rust in Contemporary Cultivars and Lines of Winter Wheat from the Eastern United States
}

Jinita Sthapit, Department of Plant Pathology, and Edward E. Gbur, Agricultural Statistics Laboratory, University of Arkansas, Fayetteville 72701; Gina Brown-Guedira, United States Department of Agriculture-Agricultural Research Service (USDA-ARS) Plant Science Research Unit, Department of Crop Science, and David S. Marshall, USDA-ARS Plant Science Research Unit, Department of Plant Pathology, North Carolina State University, Raleigh 27695; and Eugene A. Milus, Department of Plant Pathology, University of Arkansas

\begin{abstract}
Sthapit, J., Gbur, E. E., Brown-Guedira, G., Marshall, D. S., and Milus, E. A. 2012. Characterization of resistance to stripe rust in contemporary cultivars and lines of winter wheat from the eastern United States. Plant Dis. 96:737-745.

Stripe rust, caused by Puccinia striiformis f. sp. tritici, has been an important disease of winter wheat (Triticum aestivum) in the eastern United States since 2000, when a new strain of the pathogen emerged. The new strain overcame the widely used resistance gene, $Y r 9$, and was more aggressive and better adapted to warmer temperatures than the old strain. Host resistance is the most effective approach to manage stripe rust. Winter wheat lines with resistance to the new strain in the field are common, but the genes conferring this resistance are mostly unknown. The objectives of this research were to characterize the allstage resistance and adult-plant resistance (APR) to stripe rust in a representative group of contemporary winter wheat cultivars and breeding lines and to identify the resistance genes when possible. Of the 50 lines evaluated for all-stage resistance at the seedling stage, nearly all were susceptible to the new strain. Based on a linked molecular marker, seven lines had resistance gene $\operatorname{Yr} 17$ that confers resis-

tance to both old and new strains; however, this resistance was difficult to identify in the seedling stage. Of the 19 lines evaluated for APR, all expressed APR compared with a very susceptible check. Nine had race-specific APR to the new strain and nine had APR to both old and new strains. The remaining line, 26R61, had all-stage resistance to the old strain (conferred by resistance gene $\mathrm{Yr}$ ) ) and a high level of APR to the new strain. APR was expressed as low infection type, low percent leaf area diseased, and long latent period at heading stage under both low and high temperature regimes and could be identified as early as jointing stage. Based on tests for linked molecular markers, the most widely used slow-rusting APR genes, $Y r 18$ and $Y r 29$, were not present in any of the lines. The results of this research indicate that effective all-stage resistance was conferred only by $\operatorname{Yr} 17$ and that APR was common and likely conferred by unknown race-specific genes rather than genes conferring slow rusting that are more likely to be durable.
\end{abstract}

Stripe rust (yellow rust), caused by Puccinia striiformis Westend. f. sp. tritici Erikss., is an economically important foliar disease of wheat (Triticum aestivum L.) (32). In the United States before 2000, stripe rust had been common in western states and infrequent in states east of the Rocky Mountains (12). In 2000, the most widespread and severe stripe rust epidemic occurred in the United States, with stripe rust reported from 20 states east of the Rocky Mountains and being most severe in Arkansas, where yield losses were estimated to be $7 \%$ (4). All races identified in the United States before 2000 were avirulent on $\operatorname{Yr} 9$ (4). Resistance gene $\operatorname{Yr} 9$ was common among hard red winter wheat and soft red winter wheat cultivars grown east of the Rocky Mountains in 2000, and virulence on $\operatorname{Yr} 9$ likely contributed to the epidemic. Since 2000, stripe rust has been an important disease of wheat in the south-central states and Great Plains (3).

Based on an amplified fragment length polymorphism (AFLP) phenotype, the races causing epidemics east of the Rocky Mountains since 2000 are genetically distinct from races found in the United States before 2000 and are most likely the result of an exotic introduction (18). Representative isolates collected from 2000 to 2005 from the eastern United States were determined to be a single strain because they had the same AFLP phenotype based on

Corresponding author: E. A. Milus, E-mail: gmilus@uark.edu

Present address of J. Sthapit: Department of Plant Pathology, Washington State University, Pullman 99164.

Accepted for publication 9 December 2011.

http://dx.doi.org/10.1094/PDIS-07-11-0612

(C) 2012 The American Phytopathological Society the presence or absence of 130 polymorphic AFLP fragments and the same virulence phenotype (race) based on reactions on 30 differential cultivars and lines (8). Because this strain can be readily distinguished by both AFLP and virulence phenotypes from all isolates collected in the United States before 2000, it has been referred to as the "new strain", and isolates collected before 2000 have been referred to as the "old strain" $(8,21,24)$. Milus and Markell (23) showed that isolates of the new strain from the eastern United States produced intermediate infection types (ITs) that fluctuated between avirulent and virulent reactions on 4 of 20 wheat lines used to differentiate races of $P$. striiformis $\mathrm{f}$. $\mathrm{sp}$. tritici in the United States. These fluctuating ITs likely are responsible for some of the numerous races of the new strain identified in the United States (2) compared with only one race of the new strain from the United States identified by Hovmøller et al. (8).

Isolates representative of the new strain from the eastern United States were more aggressive and better adapted to warmer temperatures than isolates collected before $2000(21,24)$. Beginning in 2002 , isolates identical to those of the new strain from the eastern United States caused serious epidemics in Australia (8). Increased aggressiveness and adaptation to warmer temperatures likely contributed to the rapid replacement of old isolates by new isolates in the eastern United States and Australia (8).

Growing resistant cultivars is the most effective and economical method for managing stripe rust (13). All-stage resistance and adult-plant resistance (APR) are two major types of resistance in wheat to stripe rust (2). All-stage resistance is expressed as a low IT in the seedling stage and remains effective during all stages of plant growth, but this resistance usually is race specific and overcome by new races $(2,26)$. Some combinations of all-stage resistance genes are still effective against contemporary races, but the pathogen appears to be able to pyramid multiple virulence genes 
without a fitness penalty $(2,24)$, indicating that these combinations may not be durable.

With APR, seedlings are susceptible, but resistance is expressed at post-seedling stages. APR may be either race specific or race nonspecific and has been reported in wheat cultivars from many regions around the world $(2,9,12,15,25,29) . \mathrm{Yr} 11,-12,-13,-14$, and -16 were described as race-specific APR genes in the United Kingdom more than 30 years ago but have not been intentionally used in breeding programs because virulence for these genes is common (20). Yrl8 and -29 are genes for APR that reduce infection efficiency, increase latent period, and decrease lesion size, resulting in a slow-rusting type of resistance in the field $(29,31)$. Although Yr18 and Yr29 confer only moderate resistance when used alone, higher levels of resistance have been obtained when these genes are combined with each other or with other unnamed genes, and this resistance has remained effective against all known races $(29,31)$.

Several variables have been used to characterize the expression of APR. Qayoum and Line (26) recorded IT and percent leaf area diseased at five growth stages and six temperature regimes to characterize a type of APR called high-temperature adult-plant (HTAP) resistance that requires high temperature for expression. Cultivars with the highest level of HTAP resistance became resistant at earlier growth stages, and race specificity was not evident for this type of resistance (26). Park and Rees (25) evaluated IT, latent period, and percent leaf area diseased at various growth stages to characterize APR in Australian wheat cultivars and found that expression of APR was first evident during tillering to stem elongation stages. Ma and Singh (16) measured APR of Chinese wheat cultivars by IT, latent period, and disease severity at six growth stages.

Table 1. Pedigree for 20 wheat cultivars that were representative of cultivars grown in Arkansas in 2008 , 29 wheat lines that were selected from the 2007 United States Department of Agriculture-Agricultural Research Service Uniform Eastern Stripe Rust Nursery for having low levels of stripe rust at multiple field locations, and a very susceptible check (Croplan Genetics 514W) that were used in this study

\begin{tabular}{|c|c|}
\hline Cultivar, line & Pedigree $^{\mathrm{z}}$ \\
\hline Syngenta Coker 9553 & $89 \mathrm{M}-4035 \mathrm{~A} / 2580(=\mathrm{D} 00 * 6874-2)$ \\
\hline Syngenta Beretta & AW91M*1365/T814 (=D99-5261) \\
\hline Syngenta Magnolia & Elkhart/Mason (=D01*7759) \\
\hline AGS 2000 & 2555/PF84301//FL302 (=GA89482E7) \\
\hline \multicolumn{2}{|r|}{ (6) } \\
\hline \multicolumn{2}{|l|}{ Armor 5110} \\
\hline \multicolumn{2}{|l|}{ Croplan Genetics 554W } \\
\hline Croplan Genetics 8302 & $\begin{array}{l}\text { MYNA 'S'/5*2555 sib.//KS81H1640HF/5*2555 sib./12/2548 sib./Caldwell/11/S76 } \\
\text { sib./9/Redcoat/8/Norin33/6/Fairfield'/4/P194587//Fultz/Hungarian/3/Fultz }\end{array}$ \\
\hline \multicolumn{2}{|l|}{ Delta Grow 1600} \\
\hline \multicolumn{2}{|l|}{ Delta Grow 4500} \\
\hline \multicolumn{2}{|l|}{ Delta King 7710} \\
\hline \multicolumn{2}{|l|}{ Dixie 989} \\
\hline Hornbeck 3266 & Bowsib/2548//Ck 9877 (=LA9167=L96*9226) \\
\hline $26 \mathrm{R} 15$ & $2571 / 2540 \mathrm{sib} . / / 2552$ \\
\hline $26 \mathrm{R} 22$ & $\begin{array}{l}\text { 25R57 sib/6/2555 sib/4/Predgozaia/3/Fulbarn//BlueboyII/Ck 68-8/5/Ck 68-16/MOW7140// } \\
\text { GA 80Timwin /7/2552 }\end{array}$ \\
\hline $26 \mathrm{R} 87$ & $\begin{array}{l}\text { Avalon/3/VPM/Moisson//Champlein/Aronde/4/Ck 68-15*3/CI 14115/5/Ck 68-15*3// McNair 1813/Ck } \\
\text { 797/6/2552 }\end{array}$ \\
\hline Pat & Terral 101/2548 (=AR839-27-1-3) \\
\hline \multicolumn{2}{|l|}{ Progeny 166} \\
\hline \multicolumn{2}{|l|}{ Terral 8558} \\
\hline Terral LA841 & GA8665-D4/GA85238-C3 \\
\hline 99840C4-8-4 & 961331/INW0102//F201R/Foster \\
\hline ARS03-5929 & TX98D2106*2/TTCC251 (T.cylindricum) \\
\hline ARS05-1034 & KS2136-U142/Trego \\
\hline D03*9603 & Elkhart/D95-8294 \\
\hline E5015 & Caledonia/25W33 \\
\hline E5025 & MSU D6234/25W33 \\
\hline GA991336-6E9 & 92432//AGS 2000/26R61 \\
\hline IL02-10754 & $96-2818 / 95-4162$ \\
\hline IL87-2834-1 & Tyler/Howell \\
\hline IL99-26442 & $87-2894 / 2571$ \\
\hline KS03HW72 & KS97HW16/KS97HW206 (KS97HW206=KS91HW19/Jagger sib) (=KS5233) \\
\hline LA01112D-20-B & 26R61/GA93132-I1-17-3 \\
\hline LA02-923 & PS8424//XY90-1B/TX851212 \\
\hline LA978UC-36-1-1-B & (Ck 797/F7927-6141) 8529/90239 (CL850643/2548//Ck 9877) \\
\hline LA98005D3-1-C & 85411-C11/Mason//LA422 \\
\hline LA98113D-41-1-C & KS92WGRC23/Ck 9877//LA422'S' \\
\hline LA98133D-160-3-C & Ck 9663/26R61 \\
\hline LA98149BUB-3-4-B & FL931339AS/26R61 \\
\hline LA98214D-14-1-2-B & Shelby/87167D8-10-2(FR81-19/FL302//Ck 983) \\
\hline MD01W233-06-21 & McCormick/Choptank \\
\hline MO 021532 & MO 91-1009/AP 91-2174 \\
\hline MO 040117 & Ernie/MO 9965-52//Y88-3a \\
\hline MO 040152 & MO 12278/2571 \\
\hline NC97BGTD7 & Saluda*3/TA2492 \\
\hline Pat & Terral 101/2548 (=AR839-27-1-3) \\
\hline 26R61 & Omega78/S76/4/Arthur71/3/Stadler//Redcoat/Wisc1/5/Ck 747/6/2555sib (=XW663) \\
\hline Richland & Houser/Kleiber//White 3 way cross Composite \\
\hline Sturdy $2 \mathrm{~K}$ & Sinvalocho/Wichita//Hope/Cheyenne/3/Wichita/4/Seu Seun 27 (=TX391-56-D1-23-D19-7) \\
\hline VA05W-65 & McCormick/26R61 \\
\hline Croplan Genetics 514W & \\
\hline
\end{tabular}

${ }^{\mathrm{z}}$ Cultivars without pedigrees are branded varieties for which the pedigree is proprietary information. 
Expression of resistance was greatest at anthesis, when the lowest ITs and the longest latent periods were recorded. Hovmøller (7) evaluated APR based on disease severity in field plots inoculated with races that were virulent on seedlings.

Molecular markers have been developed that appear to be diagnostic for four stripe rust resistance genes believed to be present in some winter wheat lines from the eastern United States. A ryespecific simple-sequence repeat (SSR) marker located on chromosome arm 1RS is available for the detection of $\operatorname{Yr} 9$ (27). $\operatorname{Yr} 9$ is a race-specific, all-stage resistance gene translocated from rye ( $\mathrm{Se}$ cale cereale) through the 1BL.1RS translocation and is closely linked or pleiotropic with resistance genes Lr26 (leaf rust), Sr31 (stem rust), and $P m 8$ (powdery mildew) (20). A polymerase chain reaction marker using a pair of primers is available for detecting $\mathrm{Yrl7}$ (6). $\mathrm{Yrl7}$ is a race-specific, all-stage resistance gene located on the $2 \mathrm{NS} / 2 \mathrm{AS}$ translocation from $T$. ventricosum that is closely linked or pleiotropic with leaf rust and stem rust resistance genes Lr37 and Sr38, respectively (20). A sequence-tagged site (STS) marker (11) and a gene-specific marker (10) are available to detect the presence of $\operatorname{Yr} 18 . \mathrm{Yr} 18$ is an APR gene that is closely linked or pleiotropic with leaf rust resistance gene $\operatorname{Lr} 34$ (28). A tightly linked STS marker (G. Brown-Guedira, unpublished data) and a linked SSR marker (19) are available to detect the presence of Yr29. $Y r 29$ is an APR gene that is closely linked or pleiotropic with leaf rust resistance gene $L r 46$ (31).

Although many cultivars and breeding lines of winter wheat have resistance to the contemporary population of $P$. striiformis $\mathrm{f}$. sp. tritici in the eastern United States, little is known about the resistance. Markell et al. (17) determined that the APR in 'McCormick' and 'VA96W-270' was race specific. Hao et al. (5) determined that the major quantitative trait loci for APR in '26R61', a widely used source of stripe rust resistance in soft red winter wheat, was on chromosome 2AS. The objectives of this research were to characterize the all-stage resistance and APR to stripe rust in a representative group of contemporary winter wheat cultivars and breeding lines and to identify the resistance genes when possible. A preliminary report on this study has been published (30).

\section{Materials and Methods}

Pathogen isolates. Two isolates of $P$. striiformis f. sp. tritici were used in this study. Isolate AR90-01 (race PST-3 of the old strain) was collected in Arkansas in 1990 and is representative of the population that was present in the region east of the Rocky Mountains before 2000. Isolate AR00-05 (race PST-78 of the new strain) was collected in Arkansas in 2000 and is representative of the population east of the Rocky Mountains from 2000 to 2009. Urediniospores from storage at $-80^{\circ} \mathrm{C}$ were increased on seedlings of wheat 'Florida 302' that is susceptible to all tested races of the pathogen. Approximately 20 seeds were planted in $8-\mathrm{cm}^{2}$ pots filled with potting mix (six parts peat moss, four parts vermiculite, two parts perlite, three parts Roxana silt loam soil, and three parts sand) and incubated in a greenhouse (approximately 24 and $15^{\circ} \mathrm{C}$, day and night, respectively, and a 14-h photoperiod). At emergence and 7-day intervals after emergence, seedlings were fertilized with Peters 20-20-20 NPK fertilizer (2 g/liter). When the second leaf was 2 to $3 \mathrm{~cm}$ long, seedlings were treated with $20 \mathrm{ml}$ per pot of a 0.4-g/liter solution of 3,6 dihydroxypyridazine (a form of maleic hydrazide; Aldrich Chemical Company, Inc., Milwaukee, WI) to stop further leaf formation and enhance spore production.

Seedlings were inoculated with urediniospores suspended in Soltrol 170 mineral oil (Chevron-Phillips Chemical Co., Houston) 2 to 3 days after application of 3,6 dihydroxypyridazine. Oil on the leaves was allowed to evaporate before inoculated seedlings were incubated in a dark dew chamber at $12^{\circ} \mathrm{C}$. After approximately 24 $\mathrm{h}$, seedlings were transferred to a growth chamber programmed to change temperature gradually, with a maximum of $18^{\circ} \mathrm{C}$ at $14: 00 \mathrm{~h}$ and minimum of $12^{\circ} \mathrm{C}$ at $02: 00 \mathrm{~h}$ with a 16-h photoperiod (06:00 to 22:00). At the first appearance of symptoms, approximately 7 to 10 days after inoculation (dai), plants were covered with cello- phane bags to facilitate spore collection and prevent cross contamination. To standardize the physiological conditions, spores were produced for at least two generations as described above before being used for experiments. Urediniospores were collected several times within 14 to 28 dai, and only freshly collected spores were used as inoculum for experiments. Extra spores were dried overnight in desiccators at $5^{\circ} \mathrm{C}$ and stored at $-80^{\circ} \mathrm{C}$ for future use.

All-stage resistance. In all, 20 wheat cultivars representative of those grown in Arkansas in 2008, 29 lines selected from the United States Department of Agriculture-Agricultural Research Service (USDA-ARS) Uniform Eastern Stripe Rust Nursery for low levels of stripe rust in field, and 1 very susceptible cultivar (Croplan Genetics 514W) (Table 1) were selected for this study. To evaluate allstage resistance, the wheat lines were planted in $8-\mathrm{cm}^{2}$ pots filled with potting mix (four lines per pot with approximately six plants per line) and grown in a greenhouse as described previously. When the second leaf was 5 to $7 \mathrm{~cm}$ long, seedlings were inoculated with urediniospores of race PST-3 (isolate AR90-01) or race PST-78 (isolate AR00-05) as described previously. Each line $\times$ isolate combination was replicated twice in each experiment, and the experiment was done three times. Inoculated seedlings were incubated in a growth chamber programmed to change temperature gradually from a maximum of $18^{\circ} \mathrm{C}$ at $14: 00 \mathrm{~h}$ to a minimum of $8^{\circ} \mathrm{C}$ at $02: 00$ $\mathrm{h}$, with a 14-h photoperiod (06:00 to 20:00 h). At approximately 14 dai, ITs were recorded on the second leaves based on the 0-to-9 IT scale for stripe rust (14), in which $0=$ no visible symptoms; $1=$ necrotic or chlorotic flecks without sporulation; $2=$ necrotic or chlorotic blotches or stripes without sporulation, 3 to $7=$ necrotic or chlorotic blotches or stripes with trace, light, intermediate, moderate, and abundant sporulation, respectively; $8=$ abundant sporulation with chlorosis behind sporulating area; and $9=$ abundant sporulation without chlorosis or necrosis. ITs 0 to 4 are considered low (wheat line resistant, pathogen isolate avirulent), and ITs 5 to 8 are considered high (wheat line susceptible, pathogen isolate virulent) (4).

Additional experiments were conducted with wheat lines that likely have $\operatorname{Yr} 17$ because this resistance appeared to be difficult to identify in standard seedling evaluations as described above, and Yrl7 appeared to be the most important all-stage resistance gene protecting eastern wheat lines from stripe rust since 2000. To better identify lines with $\mathrm{Yr} 17$ in the seedling stage, seedlings of wheat lines determined to carry $\mathrm{Yr} 17$ by marker analyses were evaluated at constant 10 and $18^{\circ} \mathrm{C}$ as described by Bariana and McIntosh (1).

Resistance at heading stage. Of the 50 wheat lines tested for all-stage resistance, 20 lines were selected for characterization of APR. Nineteen lines were susceptible to races PST-3 and PST-78 in the seedling stage and one line (26R61) was susceptible to PST78 but resistant to PST-3 in the seedling stage. Croplan Genetics 554W and Croplan Genetics 514W served as susceptible and very susceptible checks, respectively. All of these lines had similar maturities. To characterize resistance at heading stage, when the expression of APR should be high, each of the 20 lines were planted ( 2 seeds per cone) on 25 November and 15 December 2008 in plastic cones (410 cc D25L Deepots; Stuewe \& Sons, Inc., Corvallis, OR) filled with potting mix. Soon after emergence, plants were thinned to one per cone and vernalized for 8 weeks in a growth chamber programmed to change temperature gradually, with a maximum of $8^{\circ} \mathrm{C}$ at $14: 00 \mathrm{~h}$ and a minimum of $5^{\circ} \mathrm{C}$ at 02:00 $\mathrm{h}$, with a $12-\mathrm{h}$ photoperiod. After vernalization, plants were transferred to a greenhouse and fertilized with Peters 20-20-20 fertilizer ( $2 \mathrm{~g} /$ liter), Soluble Trace Element Mix ( $8 \mathrm{mg}$ a.i./cone; The Scotts Company LLC, Marysville, OH), and Osmocote 14-14-14 NPK slow release fertilizer ( $3 \mathrm{~g} / \mathrm{cone}$; The Scotts Company LLC). To control aphids and thrips, plants were treated with imidacloprid (0.63 mg a.i./cone, Marathon II; Olympic Horticultural Products Co., Mainland, PA) after vernalization and every 21 days afterward until inoculation.

At heading stage (spikes fully emerged from sheath), flag and flag-1 leaves were inoculated with fresh urediniospores of races PST-3 and PST-78 (spores at $0.5 \mathrm{mg} / \mathrm{ml}$ of Soltrol 170 mineral oil) 
as described previously. Lines were inoculated when a group of four plants per line reached heading stage. Two plants were inoculated with PST-3 and the other two with PST-78. After approximately $24 \mathrm{~h}$ in a dew chamber at $12^{\circ} \mathrm{C}$, one plant inoculated with each race was transferred to a growth chamber at 10 to $18^{\circ} \mathrm{C}$ (low temperature) and the other plant was transferred to a growth chamber at 12 to $28^{\circ} \mathrm{C}$ (high temperature). Temperatures were programmed to change gradually from the highest temperature at 14:00 $\mathrm{h}$ to the lowest at 02:00 h, with a 14-h photoperiod (06:00 to 20:00). The experimental design was a full factorial with 20 wheat lines, two races, two temperatures, and three replications. The experiment was done twice. Beginning 9 dai, flag and flag- 1 leaves were examined at approximately $24-\mathrm{h}$ intervals using a $\times 4$ hand lens to determine the latent period (time from inoculation to first appearance of spores) to the nearest $12 \mathrm{~h}$. The IT and percentage of leaf area diseased $(0=0,2=$ trace to $4,7=5$ to $10,15=11$ to 20 , $30=21$ to $40,50=41$ to $60,70=61$ to $80,85=81$ to $90,93=91$ to 96 , and $98=>96 \%$ of leaf area diseased) (22) were recorded at 21 dai.

Resistance at jointing stage. The same 20 wheat lines evaluated at heading stage were inoculated at jointing stage to determine whether APR is expressed early enough to protect wheat at the growth stage when epidemics begin in the field. Lines were planted ( 1 July, 8 July, and 30 July 2009) and vernalized as described above. After vernalization, plants were fertilized as described above and kept in a growth chamber at 18 and $12^{\circ} \mathrm{C}$ (day and night, respectively) with a 14-h photoperiod for 10 days before being transferred to a greenhouse as described above. All lines within an experiment reached jointing stage at approximately the same time, and all plants in each experiment were inoculated on the same day.

At jointing stage, all of the leaves on the plants were inoculated with fresh urediniospores of races PST-3 and PST-78, as described previously. However, the spore concentration of the inoculum was doubled to $1 \mathrm{mg}$ of spores per milliliter of oil to increase the level of initial infection. Inoculated plants were incubated in a dew chamber as described previously and then transferred to a growth chamber in which the temperature was programmed to change gradually from $21^{\circ} \mathrm{C}$ at $14: 00 \mathrm{~h}$ to $8^{\circ} \mathrm{C}$ at $02: 00 \mathrm{~h}$, with a 14 -h photoperiod (06:00 to 20:00 h). This temperature regime was selected to simulate the average maximum and minimum temperatures (online at Accuweather.com) in southwest Arkansas in March when plants usually reach the jointing stage. The experimental design was a full factorial with 20 wheat lines, two isolates, and three replications. The experiment was done three times. Based on experiments at heading stage, IT was found to be the most ap- propriate variable for evaluating resistance to stripe rust; therefore, ITs on flag- 2 leaves were recorded 21 dai.

Molecular markers. Molecular markers were used to assess whether resistance genes $\mathrm{Yr} 9, \mathrm{Yr} 17, \mathrm{Yr} 18$, and $\mathrm{Yr} 29$ were present in the 50 wheat lines used in this study. Leaf samples of the 50 wheat lines and two checks (25R18 with $\operatorname{Yr} 9$ and $\operatorname{Yr} 18$ and KS0603A-50-2 with $Y r 29$ ) were sent to the USDA-ARS Eastern Regional Small Grains Genotyping Lab at Raleigh, NC. Leaf samples (approximately $25 \mathrm{mg}$ ) from each of two seedlings per line were collected and stored in 1.1-ml microtubes with silica gel before shipping to the genotyping lab.

A rye-specific SSR marker (Xscm9) located on the 1RS chromosome arm of rye (27) was used to determine the presence of $\mathrm{Yr}$ 9. For $\mathrm{Yr} 17$, a linked marker was assayed using primers (VENTRIUP-LN2) designed to amplify the $\mathrm{N}$-allele of the Xcmwg682 restriction fragment length polymorphism marker (6). The presence of APR gene Yrl8 was evaluated using the STS marker, csLV34, that maps 0.4 centimorgans $(\mathrm{cM})$ from the gene (11), and a co-dominant marker, cssfr 5 , derived directly from the $\mathrm{Yr} 18$ sequence (10). Two markers were used to determine the presence of APR gene $Y r 29$. Xwmc44 is an SSR marker that is $12.5 \mathrm{cM}$ from the gene (19), and XBarc_NC_39 is a tightly linked STS marker (G. Brown-Guedira, unpublished data).

Statistical analysis. Data for percentage of leaf area diseased and latent period at heading stage were analyzed using Proc GLM, SAS (version 9.1.3; SAS Institute, Cary, NC) as an unbalanced split plot with two post-inoculation temperatures and two repetitions of the experiment as the whole plot and a factorial of 20 wheat lines and two pathogen races, each combination of which was replicated three times, as the split plot. Temperature, race, line, and their interactions were treated as fixed effects. Repetition and replication were treated as random effects. Based on results of analysis of variance, the appropriate means were separated using least significant difference (LSD) tests at $P=0.05$ based on the number of observations for each mean.

Summarizing APR results across all experiments. To objectively determine the race specificity and temperature sensitivity of the APR in each line, all relevant comparisons (PST-3 versus PST78 and low temperature versus high temperature, respectively) were made across all of the experiments in this study. These were summarized as the number of comparisons supporting race specificity and temperature sensitivity (i.e., HTAP resistance). The nine comparisons for race specificity were as follows: four based on IT at heading stage (two leaf positions by two temperatures), four based on latent period and percentage of leaf area diseased on

Table 2. Presence of molecular markers in the 11 wheat lines and two checks that were positive for one or more of the six tested markers for four $Y r$ resistance genes ${ }^{t}$

\begin{tabular}{|c|c|c|c|c|c|c|}
\hline \multirow[b]{2}{*}{ Line } & \multirow{2}{*}{$\frac{Y r 9}{X s c m 9^{u}}$} & \multirow{2}{*}{$\begin{array}{c}\text { Yr17 } \\
\text { Xcmwg682 }\end{array}$} & \multicolumn{2}{|c|}{ Yr18 } & \multicolumn{2}{|c|}{ Yr29 } \\
\hline & & & $\operatorname{csLV34}^{\mathrm{w}}$ & $\operatorname{cssfr} 5^{\mathrm{x}}$ & XBarc_NC_39y & $X w m c 44^{\mathrm{z}}$ \\
\hline $26 \mathrm{R} 61$ & $\mathrm{Y}$ & - & - & - & - & $\mathrm{Y}$ \\
\hline 26R87 & - & Y & - & - & - & - \\
\hline $99840 \mathrm{C} 4-8-4$ & $\mathrm{Y}$ & $\mathrm{Y}$ & - & - & - & - \\
\hline AGS 2000 & Y & - & _- & - & - & $\mathrm{Y}$ \\
\hline ARS05-1034 & - & $\mathrm{H}$ & - & - & - & $\mathrm{H}$ \\
\hline GA991336-6E9 & - & $\mathrm{Y}$ & - & - & - & $\mathrm{Y}$ \\
\hline KS03HW72 & - & Y & - & _- & - & $\mathrm{Y}$ \\
\hline LA01112D-20-B & $\mathrm{Y}$ & - & - & - & - & - \\
\hline LA98149BUB-3-4-B & - & - & - & - & - & $\mathrm{Y}$ \\
\hline LA98214D-14-1-2-B & - & $\mathrm{Y}$ & - & - & - & - \\
\hline Terral LA 841 & _- & $\mathrm{Y}$ & - & _- & _- & _- \\
\hline 25R18 ( $\mathrm{Yr} 9$ and $\mathrm{Yr} 18$ check) & Y & - & $\mathrm{Y}$ & Y & - & - \\
\hline KS0603A-50 (Yr29 check) & $\mathrm{Y}$ & $\mathrm{Y}$ & - & - & - & $\mathrm{Y}$ \\
\hline
\end{tabular}

${ }^{\mathrm{t}} \mathrm{Y}=$ molecular marker was present, $-=$ molecular marker was absent, and $\mathrm{H}=$ heterogeneous, marker was present in only one of the two plants tested.

" A rye-specific simple-sequence repeat (SSR) marker on chromosome arm 1RS (27).

${ }^{v}$ A marker that is assayed by a pair of primers VENTRIUP-LN2 (6).

${ }^{\mathrm{w}}$ A sequence-tagged site (STS) marker that is 0.4 centimorgans (cM) from the gene (11).

${ }^{x}$ A co-dominant marker that is a portion of the gene (10).

${ }^{y}$ A tightly-linked STS marker (G. Brown-Guedira, unpublished).

${ }^{\mathrm{z}}$ An SSR marker that is $12.5 \mathrm{cM}$ proximal to the gene (19). 
two leaf positions, and one based on IT at jointing stage. Resistance was considered race specific for PST-78 when the percentage of leaf area diseased was significantly lower $(P=0.05)$ or the latent period was significantly longer $(P=0.05)$ for PST-78 than for PST-3 or when the predominant IT for PST-78 was at least three IT classes lower than the predominant IT for PST-3 on the 0-to-9 scale. Twelve comparisons for temperature sensitivity were based on evaluations at heading stage (two leaf positions by two races by three variables [IT, latent period, and percentage of leaf area diseased]). A line had resistance requiring high temperature for expression when the percentage of leaf area diseased was significantly lower $(P=0.05)$ or the latent period was significantly longer $(P=0.05)$ at 12 to $28^{\circ} \mathrm{C}$ than at 10 to $18^{\circ} \mathrm{C}$ or when the predominant IT at 12 to $28^{\circ} \mathrm{C}$ was at least three IT classes lower than the predominant IT at 10 to $18^{\circ} \mathrm{C}$.

\section{Results}

All-stage resistance. Based on assays of the 50 wheat lines for molecular markers linked to all-stage resistance genes $\operatorname{Yr} 9$ and $\operatorname{Yr} 17$, the check lines (25R18), 26R61, AGS 2000, 99840C4-8-4, and LA01112D-20-B were positive for the marker Xscm 9 that is linked to $\operatorname{Yr} 9$, and lines 26R87, Terral LA 841, 99840C4-8-4, ARS05-1034, GA991336-6E9, KS03HW72, and LA98214D-14-1-2-B were positive for the marker Xcmwg682 that is linked to $\operatorname{Yrl7}$ (Table 2).

Among seedlings of the 20 cultivars grown in Arkansas, ITs on AGS 2000 that has the marker for $Y r 9$ ranged from 0 to 2 and 7 to 8 for PST-3 and PST-78, respectively. ITs on Terral LA 841 and 26R87 that have the marker for $\mathrm{Yrl} 17$ ranged from 2 to 4 with both races, except for 26R87 inoculated with PST-78, that had ITs ranging from 0 to 6 (Fig. 1A). 26R15 appears to have an unknown resistance gene that conditions IT ranges of 3 to 5 and 5 to 8 with PST-3 and PST-78, respectively. For the remaining 16 cultivars, ITs with both races were generally 7 or 8 , indicating a lack of effective all-stage resistance.

Among seedlings of the 29 lines selected from the USDA-ARS Uniform Eastern Stripe Rust Nursery and the very susceptible cultivar (Croplan Genetics 514W), ITs on LA01112D-20-B and 26R61 that have the marker for $\operatorname{Yr} 9$ ranged from 0 to 2 with PST-3 and were mostly higher than 6 with PST-78 (Fig. 1B). ITs on lines ARS05-1034, GA991336-6E9, KS03HW72, and LA98214D-14-12-B that have the marker for Yrl7 ranged from 1 to 8 with PST-3 and from 3 to 8 with PST-78. However, most of the ITs were 6 or higher with both races that are avirulent on $\operatorname{Yr17}$. ITs on 99840C48-4, that has markers for both $\operatorname{Yr} 9$ and $\operatorname{Yr} 17$, were 0 or 1 with PST3 and ranged from 2 to 5 with PST-78. ITs on Richland were 0 or 2 with PST-3 and were usually 6 or higher with PST-78, indicating that Richland has an unknown gene conditioning all-stage resistance to PST-3 but not PST-78. ITs on the remaining 22 lines generally were 7 to 8 , indicating no effective all-stage resistance to races PST-3 or PST-78.

When seedlings of lines with $\operatorname{Yr} 17$ were inoculated with the avirulent races PST-3 and PST-78 and incubated at constant $10^{\circ} \mathrm{C}$, ITs were 8 to 9 , except for line $99840 \mathrm{C} 4-8-4$, that also had $\mathrm{Yr} 9$ (Table 3). When the seedlings were incubated at constant $18^{\circ} \mathrm{C}$, ITs were $2+8$, except for line $99840 \mathrm{C} 4-8-4$. The $2+8$ IT was unusual in that chlorotic and necrotic areas without sporulation developed by 14 dai, and then the pathogen sporulated well on the surrounding green leaf tissue by 19 dai. ITs on line 99840 C4-8-4 were low (0 to 2) with race PST-3 regardless of temperature but were $2+8$ and 2 to 3 with race PST-78 at 10 and $18^{\circ} \mathrm{C}$, respectively.

Markers for APR genes $\mathbf{Y r 1 8}$ and Yr29. Markers csLV34 and cssfr5 linked to $\operatorname{Yr} 18$ were detected in the positive check 25R18 (Table 2) but not in any of the lines in this study. Among the two markers for $Y r 29$, Xwmc44 was present in the positive check (KS0603A-50) and six lines (26R61, AGS 2000, ARS05-1034, GA991336-6E9, KS03HW72, and LA98149BUB-3-4-B) but XBarc_NC_39 was not present in any of lines, including the positive check.

Resistance at heading stage. For the percentage of flag leaf area diseased, 44 of 480 observations (9.2\%) were missing because there were no symptoms of infection or the flag leaf died prematurely due to mechanical breakage from handling plants. For latent period on flag leaves, 232 of 480 observations (48.3\%) were missing. These missing values included the 44 observations described above and 188 observations with IT 1 or 2 that had no sporulation and, therefore, no latent period. These missing data necessitated analyses accounting for unbalanced data.

Statistical analysis accounting for the unbalanced data of percentage of flag leaf area diseased showed significant temperature $\times$ race $(P=0.0170)$ and race $\times$ line $(P<0.0001)$ interactions (Table 4). The significant temperature $\times$ race interaction was due to the magnitude of the differences between races PST-3 and PST-78 at the low and high temperature regimes rather than a change in ranking. Race PST-3 caused 2.9 times more diseased area than race PST-78 at 12 to $28^{\circ} \mathrm{C}$ but only 2.6 times more at 10 to $18^{\circ} \mathrm{C}$ (data not shown).

Because the race $\times$ line interaction for percentage of flag leaf area diseased was significant, the race $\times$ line interaction means were compared using LSD values based on the number of observations for each mean (Table 5). Croplan Genetics 514W (very susceptible check) had similar percentages of flag leaf area diseased with both races that were significantly higher than those of other lines, except for MO021532 and NC97BGTD7 inoculated with PST-3. Croplan Genetics 554W (susceptible check) also had similar percentages of flag leaf area diseased with both races, but these values were not significantly different from the most resistant lines. Seven lines (NC97BGTD7, MO021532, LA98113D-41-1-C, VA05W-65, Delta King 7710, Progeny 166, and Syngenta Beretta) had significantly higher percentages of flag leaf area diseased with race PST-3 than with race PST-78, indicating race-specific resistance to PST-78. Percentages of flag leaf area diseased for the remaining 11 lines were not significantly different for the two races, indicating that these lines had similar levels of APR to both races.

Statistical analysis accounting for the unbalanced data of latent period on flag leaves showed a significant race $\times$ line interaction $(P$ $=0.0007$; Table 4). The latent period of both races was shortest on the very susceptible line Croplan Genetics 514W (Table 5). Latent periods of both races were similar on the susceptible line Croplan Genetics $554 \mathrm{~W}$ and significantly longer than the latent periods on Croplan Genetics 514W, indicating that Croplan Genetics 554W has at least one resistance gene that is effective against both races. Except for the latent periods on VA05W-65, NC97BGTD7, MO 021532, MD01W233-06-21, and Delta Grow 4500 inoculated with PST-3, latent periods on all the other lines were significantly longer than that on Croplan Genetics 514W for the two races, indicating the presence of resistance. Latent periods of PST-78 were significantly longer than those of PST-3 on four lines (NC97BGTD7, MD01W233-06-21, LA98113D-41-1-C, and 26R22), indicating a race-specific reaction. For five lines (VA05W65, MO 021532, Delta King 7710, ARS03-5929, and 26R61), latent period data could not be calculated for one of the races because there was no sporulation on any of the leaves (i.e., IT $\leq 2$ ), indicating a high level of resistance. Latent periods on the remaining nine lines were similar for the two races.

On flag leaves, ITs on the very susceptible check (Croplan Genetics 514W) were high (IT 8 to 9) with both races at both temperature regimes, indicating susceptibility to both races and no effect of temperature (Table 5). ITs on the susceptible check (Croplan Genetics 554W) were 8 to 7 at 10 to $18^{\circ} \mathrm{C}$ and 8 to 5 at 12 to $28^{\circ} \mathrm{C}$, indicating susceptibility at low temperature and a shift to moderate susceptibility at high temperature. The IT of PST-3 on 26R61 was 0 due to resistance conditioned by the all-stage resistance gene $\operatorname{Yr} 9$, and the IT with PST-78 was low at both temperatures, indicating a high level of APR that was not affected by temperature.

At both temperature regimes, ITs on six lines (MO 021532, LA98113D-41-1-C, VA05W-65, Delta King 7710, Progeny 166, and MD01W233-06-21) were high to intermediate with PST-3, indicating they were susceptible to moderately susceptible to PST- 
3, but ITs were low to intermediate with PST-78, indicating they were highly to moderately resistant to PST-78. Four additional lines (ARS03-5929, 26R22, Delta Grow 4500, and Armor 5110) showed race specificity at 10 to $18^{\circ} \mathrm{C}$ but not at 12 to $28^{\circ} \mathrm{C}$. ITs for both races were similar on the other lines, indicating no race specificity with these two races.

ITs for PST-3 on six lines (LA98113D-41-1-C, Progeny 166, ARS03-5929, Delta Grow 4500, Armor 5110, and Delta Grow 1600) and for PST-78 on Sturdy $2 \mathrm{~K}$ were lower at 12 to $28^{\circ} \mathrm{C}$ than at 10 to $18^{\circ} \mathrm{C}$, indicating that resistance was expressed to a greater degree at the high temperature regime. ITs on the other cultivars were similar at both temperature regimes, indicating that high temperature was not necessary for maximal expression of resistance.

Results for percent leaf area diseased, latent period, and IT on Flag-1 leaves at 10 to 18 and 12 to $28^{\circ} \mathrm{C}$ were similar (data not shown) and were included in the summary across all experiments and variables (below).

Resistance at jointing stage. On flag- 2 leaves at jointing stage, ITs were 8 and 8 to 6 for both races on Croplan Genetics 514W and Croplan Genetics 554W, respectively, indicating that both

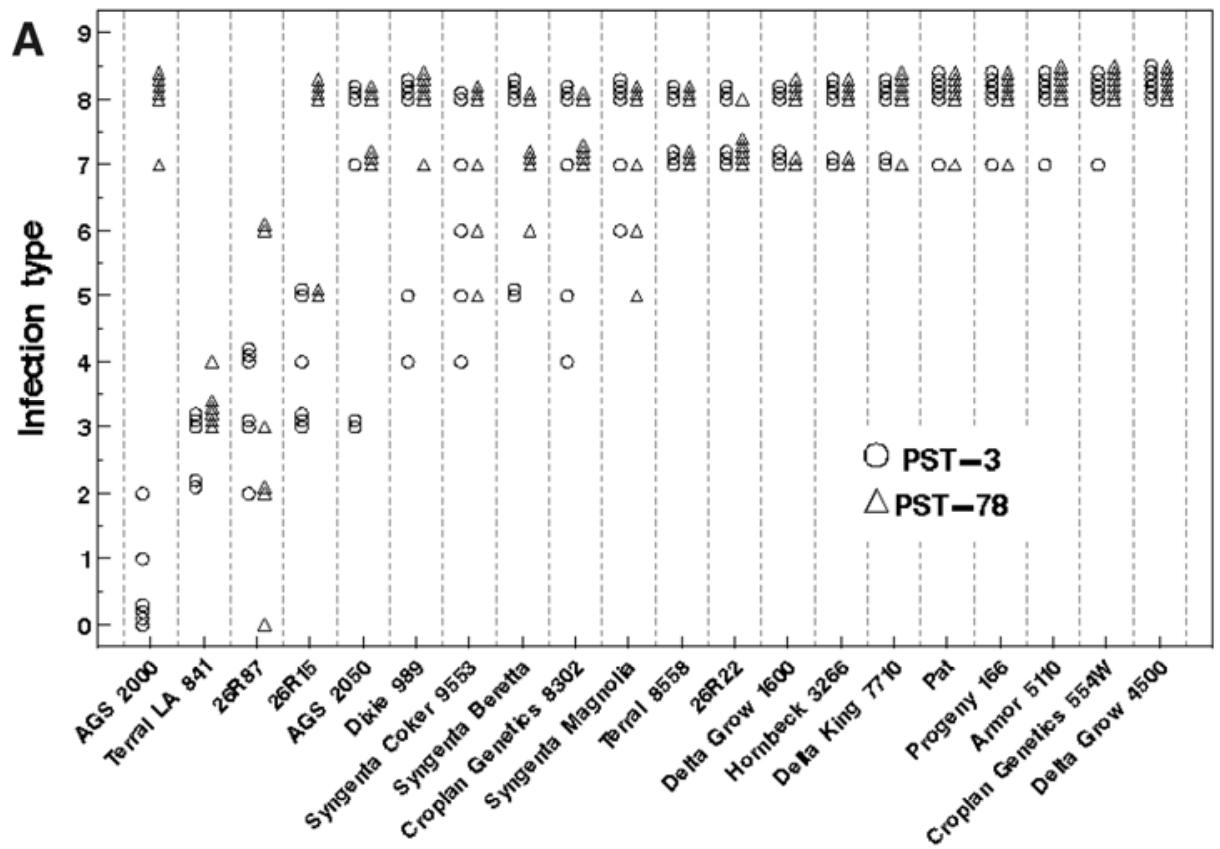

Cultivars
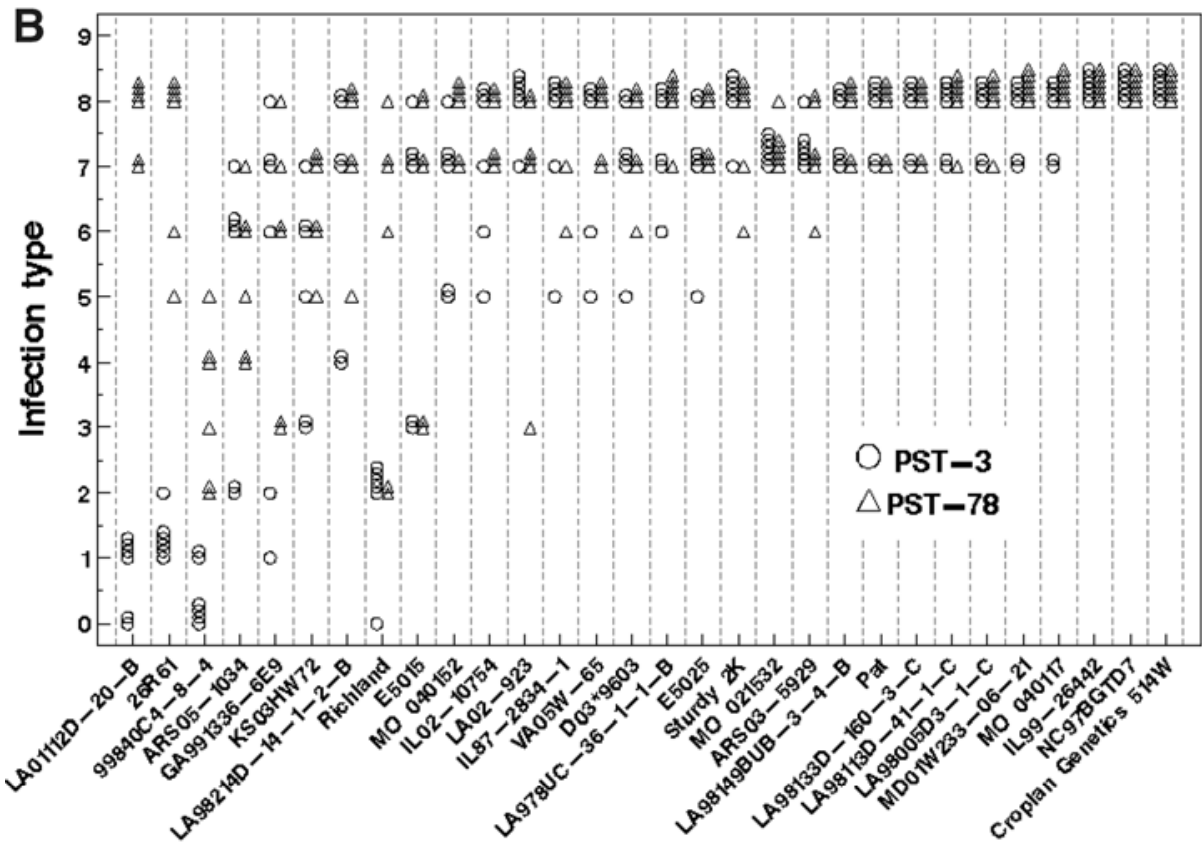

Lines

Fig. 1. Summary of infection type data for seedlings inoculated with races PST-3 and PST-78 of Puccinia striformis f. sp. tritici and incubated for 14 days at 8 to $18^{\circ} \mathrm{C}$ with a gradually changing temperature regime and 14-h photoperiod. Each point represents the infection type on a clump of four to six seedlings in each of three repetitions of the experiment with two replications each. Where infection type was the same within a cultivar and race, the points were adjusted slightly to show individual points; $\mathbf{A}, 20$ wheat cultivars representative of those grown in Arkansas in 2008 and B, 29 wheat lines selected from the 2007 United States Department of Agriculture-Agricultural Research Service Uniform Eastern Stripe Rust Nursery and a very susceptible check (Croplan Genetics 514W). 
cultivars were susceptible to both races (Table 5). ITs for race PST3 were low on ARS03-5929 and 26R61 and high to intermediate on the remaining lines. Differences between ITs of PST-3 and PST78 were great enough on eight lines (MO 021532, LA98113D-411-C, VA05W-65, Delta King 7710, Progeny 166, 26R22, Delta Grow 4500, and Armor 5110) to be considered race specific for PST-78. Overall, ITs at jointing stage indicated that APR was expressed at this growth stage and temperature regime.

Summarizing APR results across all experiments. Results were summarized across all experiments to determine the race specificity and temperature sensitivity of APR in each line (Table 6). Nine lines (LA98113D-41-1-C, MO 021532, VA05W-65, Delta King 7710, 26R22, MD01W233-06-21, Progeny 166, NC97BGTD7, and ARS03-5929) were race specific for five or more of the nine total comparisons (PST-3 versus PST-78) and were considered to have race-specific APR for the new strain. The remaining nine lines showed race specificity in fewer than five pairwise comparisons and were considered to have APR that was effective against both old and new strains. 26R61 has all-stage resistance to the old strain and high level of APR to the new strain. There was no evidence for APR that was race specific for the old strain.

Among the 12 comparisons (low versus high temperature regimes), the lines that showed a higher level of resistance at high temperature $\left(12\right.$ to $\left.28^{\circ} \mathrm{C}\right)$ in at least six variables were determined to express APR more effectively at high temperature. Only Sturdy $2 \mathrm{~K}$ expressed a higher level of resistance at the high temperature regime (Table 6). The remaining 18 lines expressed little or no difference in expression of APR between the low and high temperature regimes.

\section{Discussion}

The results of this study indicated that effective all-stage resistance against the new strain of $P$. striiformis f. $\mathrm{sp}$. tritici (represented by race PST-78) was not common among the 50 contemporary winter wheat cultivars and advanced breeding lines in this study and that $\operatorname{Yr} 17$ was the only effective all-stage resistance gene. Based on the presence of the Xcmwg682 molecular marker for $\mathrm{Yr} 17$, this gene appears to be present in seven lines (Terral LA 841, 99840C4-8-4, 26R87, ARS05-1034, GA9913366E9, KS03HW72, and LA98214D-14-1-2-B) but the IT on seedlings of these lines did not consistently support the presence of Yr17. This inability to consistently detect $\operatorname{Yrl7}$ using IT on seedlings agrees with the work of Bariana and McIntosh (1), who concluded that the expression of $\mathrm{Yr} 17$ depends on the environment and background genotype. Because the reaction of $\mathrm{Yrl7}$ is variable at the seedling stage, especially at temperatures commonly used for seedling assays and race identification, $\operatorname{Yrl7}$ appears to be better classified as a gene for APR rather than a gene for all-stage resistance. Furthermore, $\operatorname{Lr} 37$ for leaf rust resistance that likely is pleiotropic with $\operatorname{Yrl7}$ is classified as an APR gene (20). Although Yrl7 protected wheat from all races found in the eastern United States at the time of this study, a new race with virulence on $\mathrm{Yr} 17$ was widespread in the south-central United States in 2010 and 2011 (E. A. Milus, unpublished data).

The results of this study also indicated that APR was common among contemporary winter wheat cultivars and advanced breeding lines and provided effective protection against the new strain of P. striiformis f. sp. tritici. All 19 lines that were evaluated for APR (including the susceptible check Croplan Genetics 554W) expressed some level of APR relative to the very susceptible check (Croplan Genetics 514W). Summarized results across all experiments and variables in this study demonstrated that the APR in at least nine wheat lines (LA98113D-41-1-C, MO 021532, VA05W65, Delta King 7710, Progeny 166, 26R22, MD01W233-06-21, ARS03-5929, and NC97BGTD7) was more effective against PST78 than PST-3 and, therefore, race specific for PST-78. Of the remaining 10 lines with APR against both races, two (Sturdy $2 \mathrm{~K}$ and 26R61) had ITs that were predominantly $\leq 3$ at heading stage, indicating that the APR in these lines likely is race specific rather than a more durable, slow-rusting resistance. Data from X. Chen that were cited by Hao et al. (5) show that the APR in 26R61 was over-

Table 3. Infection types produced by races PST-3 and PST-78 of Puccinia striiformis f. sp. tritici on wheat lines determined to have resistance gene Yr17 when incubated for 19 days after inoculation (dai) at constant 10 or $18^{\circ} \mathrm{C}$ with a 14 -h photoperiod

\begin{tabular}{|c|c|c|c|c|c|}
\hline \multirow[b]{3}{*}{ Line $^{\mathrm{z}}$} & \multirow[b]{3}{*}{ Yr gene } & \multicolumn{4}{|c|}{ Infection type (0-to-9 scale $)^{y}$} \\
\hline & & \multicolumn{2}{|c|}{ PST-3 } & \multicolumn{2}{|c|}{ PST-78 } \\
\hline & & $10^{\circ} \mathrm{C}$ & $18^{\circ} \mathrm{C}$ & $10^{\circ} \mathrm{C}$ & $18^{\circ} \mathrm{C}$ \\
\hline LA98214D-14-1-2-B & 17 & $8-9$ & $2+8$ & $8-9$ & $2+8$ \\
\hline GA991336-6E9 & 17 & $8-9$ & $2+8$ & $8-9$ & $2+8$ \\
\hline KS03HW72 & 17 & $8-9$ & $2+8$ & $8-9$ & $2+8$ \\
\hline 26R87 & 17 & 8 & $2+8$ & $8-9$ & $2+8$ \\
\hline Terral LA 841 & 17 & 8 & $2+8$ & $8-9$ & $2+8$ \\
\hline $99840 \mathrm{C} 4-8-4$ & 9,17 & 2 & $0-1$ & $2+8$ & $2-3$ \\
\hline Croplan Genetics 514W & None & $8-9$ & 8 & $8-9$ & 8 \\
\hline
\end{tabular}

y Numbers connected by "-" indicate a range of infection types across two replicates in each of two experiments and by "+" indicate two distinct infection types on the same leaf across two replicates of two experiments. More specifically, the $2+8$ infection type begins with type 2 chlorotic and necrotic areas at 12 to 14 dai and evolves into type 8 by 19 dai on leaf tissue above and below the chlorotic and necrotic areas.

${ }^{\mathrm{z}}$ Line ARS05-1034 that was determined to be heterogeneous for $\mathrm{Yr} 17$ could not be evaluated in this experiment due to a lack of seed. Croplan Genetics $514 \mathrm{~W}$ was included as a susceptible check.

Table 4. Statistical tests accounting for unbalanced data for the fixed effects of temperature, race, line, and their interactions for percentage of flag leaf area diseased and latent period of flag leaves on 20 wheat lines inoculated with races PST-3 and PST-78 of Puccinia striiformis f. sp. tritici at heading stage and incubated at 10 to $18^{\circ} \mathrm{C}$ (low) and 12 to $28^{\circ} \mathrm{C}$ (high) gradually changing temperature regimes

\begin{tabular}{|c|c|c|c|c|c|c|}
\hline \multirow[b]{2}{*}{ Source } & \multicolumn{3}{|c|}{ Flag leaf area diseased $(\%)$} & \multicolumn{3}{|c|}{ Latent period on flag leaves } \\
\hline & df & $F$ value & Probability $>F$ & df & $F$ value & Probability $>F$ \\
\hline Temperature & 1 & 8.52 & 0.2101 & 1 & 0.95 & 0.4516 \\
\hline Race & 1 & 65.93 & $<0.0001$ & 1 & 3.83 & 0.0550 \\
\hline Line & 19 & 14.40 & $<0.0001$ & 19 & 5.59 & $<0.0001$ \\
\hline Temperature $\times$ race & 1 & 5.92 & 0.0170 & 1 & 0.84 & 0.3633 \\
\hline Temperature $\times$ line & 19 & 1.58 & 0.0823 & 16 & 0.80 & 0.6806 \\
\hline Race $\times$ line & 19 & 5.15 & $<0.0001$ & 12 & 3.53 & 0.0007 \\
\hline Temperature $\times$ race $\times$ line & 19 & 0.53 & 0.9407 & 9 & 0.68 & 0.7212 \\
\hline
\end{tabular}


come by race PST-127, indicating that the resistance is race specific.

Based on summarized results across all comparisons of the level of APR at high and low temperatures, the levels of APR in all except one line were similar at the low $\left(10\right.$ to $\left.18^{\circ} \mathrm{C}\right)$ and high $(12$ to $28^{\circ} \mathrm{C}$ ) temperature regimes used in this study. Only Sturdy $2 \mathrm{~K}$ expressed a higher level of resistance at the high temperature regime for at least half of the comparisons. Furthermore, all lines with APR expressed resistance at jointing stage under a temperature regime of 8 to $21^{\circ} \mathrm{C}$ that is similar to one of the low temperature regimes (6 to $21^{\circ} \mathrm{C}$ ) used by Qayoum and Line (26) to describe HTAP resistance. These results indicate that the APR in this study does not appear to be HTAP resistance.

A molecular marker can be used as a diagnostic tool to detect a gene of interest if the marker is always linked to the gene. The marker Xscm 9 appeared to be diagnostic for the presence of $\operatorname{Yr} 9$, because the marker data always agreed with the phenotypic IT data at the seedling stage. The marker Xcmwg682 appears to be diagnostic for $\operatorname{Yr17}$, but ITs on seedlings were too variable to definitively determine which lines have $\operatorname{Yr} 17$ based on IT data at the seedling stage. The markers csLV34 and cssfr 5 , used to detect Yr18, were reported to be closely linked to (11) and within (10) the $\operatorname{Yr} 18$ gene, respectively; and, therefore, should be diagnostic for the presence of $\operatorname{Yr} 18$. Both markers were present in 25R18, the positive check for $\operatorname{Yr} 18$, but absent in all of the other lines, indicating that none of the tested winter wheat lines have $\operatorname{Yr} 18$. Of the two markers used to detect Yr29, XBarc_NC_39 (G. BrownGuedira, unpublished) was not polymorphic among any of the tested lines, including KS0603A-50 that was included as a positive check for Yr29. The other marker, Xwmc44 (19), was present in the positive check and six other lines, but the pedigrees for the six lines do not include a known source of $Y r 29$. Marker Xwmc44 was not diagnostic for $Y r 29$, and further research is needed to resolve the status of XBarc_NC_39 as a diagnostic marker for Yr29.

Race-specific APR appears to be the most frequent and important type of stripe rust resistance among the wheat lines in this study. Although this APR is effective against the present population of $P$. striiformis f. sp. tritici in the eastern United States, the resistance is not likely to be durable, as demonstrated by the ability of race PST-127 to overcome the APR in 26R61 (5). Given that cultivars with race-specific APR are grown across a large area of the eastern United States, the emergence of races that are defined by their abilities to overcome APR genes should be expected. Finally, incorporation of durable APR genes such as $\mathrm{Yr} 18, \mathrm{Yr} 29$,

Table 6. Summary of results across all adult-plant experiments to determine the race specificity of adult-plant resistance (APR) and the effect of high temperature on the expression of APR in 20 wheat lines inoculated with races PST-3 and PST-78 of Puccinia striiformis f. sp. tritici

\begin{tabular}{|c|c|c|}
\hline Line & $\begin{array}{c}\text { Race } \\
\text { specificity }^{x}\end{array}$ & $\begin{array}{l}\text { Effect of high } \\
\text { temperature }^{y}\end{array}$ \\
\hline LA98113D-41-1-C & 9 & 4 \\
\hline MO 021532 & 9 & 2 \\
\hline VA05W-65 & 9 & 1 \\
\hline Delta King 7710 & 8 & 0 \\
\hline Progeny 166 & 7 & 3 \\
\hline $26 \mathrm{R} 22$ & 7 & 1 \\
\hline MD01W233-06-21 & 7 & 1 \\
\hline ARS03-5929 & 5 & 2 \\
\hline NC97BGTD7 & 5 & 1 \\
\hline Delta Grow 4500 & 4 & 4 \\
\hline Armor 5110 & 4 & 2 \\
\hline LA978UC-36-1-1-B & 3 & 0 \\
\hline Syngenta Beretta & 2 & 3 \\
\hline Terral TV 8558 & 2 & 0 \\
\hline Sturdy $2 \mathrm{~K}$ & 1 & 6 \\
\hline Delta Grow 1600 & 1 & 3 \\
\hline Pat & 1 & 2 \\
\hline Croplan Genetics 554W & 1 & 1 \\
\hline 26R61 & $0^{\mathrm{z}}$ & 2 \\
\hline Croplan Genetics 514W & 0 & 0 \\
\hline
\end{tabular}

${ }^{x}$ Sum of the number of variables (maximum score 9) for which the line showed race-specific APR.

y Sum of the number of variables (maximum score 12) for which the line showed more effective APR at the high temperature regime $\left(12\right.$ to $\left.28^{\circ} \mathrm{C}\right)$ than at the low temperature regime $\left(10\right.$ to $\left.18^{\circ} \mathrm{C}\right)$.

${ }^{\mathrm{z}}$ Not determined because of all-stage resistance to race PST-3.

Table 5. Percentage of leaf area diseased, latent period, and infection type (IT) on flag leaves of 20 wheat lines inoculated at heading stage with races PST-3 and PST-78 of Puccinia striiformis f. sp. tritici and incubated at 10 to $18^{\circ} \mathrm{C}$ (low) and 12 to $28^{\circ} \mathrm{C}$ (high) gradually changing temperature regimes and IT on flag-2 leaves inoculated at jointing stage and incubated at an 8 to $21^{\circ} \mathrm{C}$ gradually changing temperature regime

\begin{tabular}{|c|c|c|c|c|c|c|c|c|c|c|}
\hline \multirow[b]{3}{*}{ Line } & \multicolumn{8}{|c|}{ Flag leaf } & \multirow{2}{*}{\multicolumn{2}{|c|}{$\begin{array}{c}\text { Flag-2 leaf } \\
\text { IT }^{\mathrm{z}}\end{array}$}} \\
\hline & \multicolumn{2}{|c|}{ Leaf area diseased $(\%)^{y}$} & \multicolumn{2}{|c|}{ Latent period (days) $^{y}$} & \multicolumn{2}{|c|}{ IT $\left(10-18^{\circ} \mathrm{C}\right)^{\mathrm{z}}$} & \multicolumn{2}{|c|}{ IT $\left(12-28^{\circ} \mathrm{C}\right)^{\mathrm{z}}$} & & \\
\hline & PST-3 & PST-78 & PST-3 & PST-78 & PST-3 & PST-78 & PST-3 & PST-78 & PST-3 & PST-78 \\
\hline Croplan Genetics 514W & $54.8 \mathrm{j}$ & $67.8 \mathrm{j}$ & $10.3 \mathrm{ab}$ & $9.1 \mathrm{a}$ & $9-8$ & 9 & 8 & $8-9$ & 8 & 8 \\
\hline Croplan Genetics 554W & $10.4 \mathrm{a}-\mathrm{g}$ & $7.4 \mathrm{a}-\mathrm{e}$ & $11.9 \mathrm{c}-\mathrm{g}$ & $12.0 \mathrm{~d}-\mathrm{g}$ & 8 & $8-7$ & $8-5$ & $8-5$ & $8-6$ & $8-6$ \\
\hline NC97BGTD7 & $59.7 \mathrm{j}$ & $21.7 \mathrm{~d}-\mathrm{i}$ & $10.7 b-d$ & $13.0 \mathrm{f}-\mathrm{h}$ & $9-7$ & $7-5$ & 7 & $7-4$ & $8-6$ & $6-2$ \\
\hline MO 021532 & $57.1 \mathrm{j}$ & $1.4 \mathrm{a}$ & $10.8 \mathrm{~b}-\mathrm{d}$ & & $8-7$ & $0-3$ & $8-6$ & $0-3$ & $8-6$ & $4-2$ \\
\hline LA98113D-41-1-C & $25.8 \mathrm{~g}-\mathrm{i}$ & $1.9 \mathrm{ab}$ & $11.7 \mathrm{c}-\mathrm{e}$ & $15.7 \mathrm{i}$ & $9-7$ & $0-5$ & $5-7$ & $0-3$ & $7-5$ & $2-5$ \\
\hline VA05W-65 & $21.0 \mathrm{~d}-\mathrm{i}$ & $0.2 \mathrm{a}$ & $10.5 \mathrm{bc}$ & 20 & $9-7$ & 0 & $7-8$ & 0 & $7-6$ & $2-5$ \\
\hline Delta King 7710 & $18.0 \mathrm{c}-\mathrm{i}$ & $0.8 \mathrm{a}$ & $12.0 \mathrm{~d}-\mathrm{g}$ & $\ldots$ & $8-7$ & 0 & $6-4$ & 0 & $8-5$ & $1-4$ \\
\hline Progeny 166 & $29.8 \mathrm{i}$ & $9.8 \mathrm{a}-\mathrm{e}$ & $11.7 \mathrm{c}-\mathrm{e}$ & $12.3 \mathrm{~d}-\mathrm{h}$ & $8-6$ & $0-6$ & $4-5$ & $0-3$ & $7-4$ & $3-5$ \\
\hline Syngenta Beretta & $27.8 \mathrm{hi}$ & $10.3 \mathrm{a}-\mathrm{f}$ & $12.3 \mathrm{e}-\mathrm{h}$ & $11.1 \mathrm{~b}-\mathrm{e}$ & $7-5$ & $5-0$ & $5-4$ & $3-0$ & $7-5$ & $6-3$ \\
\hline ARS03-5929 & $6.8 \mathrm{a}-\mathrm{d}$ & $0.2 \mathrm{a}$ & $13.8 \mathrm{~g}-\mathrm{i}$ & & $7-5$ & 0 & $2-3$ & 0 & $2-4$ & $0-1$ \\
\hline MD01W233-06-21 & $9.8 \mathrm{a}-\mathrm{e}$ & $1.5 \mathrm{a}$ & $11.5 \mathrm{~b}-\mathrm{e}$ & $14.1 \mathrm{hi}$ & $8-5$ & $0-4$ & $8-6$ & $0-4$ & $7-5$ & $5-3$ \\
\hline $26 \mathrm{R} 22$ & $20.9 \mathrm{~d}-\mathrm{i}$ & $7.9 \mathrm{a}-\mathrm{e}$ & $12.0 \mathrm{~d}-\mathrm{g}$ & $14.2 \mathrm{hi}$ & $8-7$ & $5-0$ & $6-4$ & $4-0$ & $7-6$ & $4-2$ \\
\hline Delta Grow 4500 & $25.7 \mathrm{f}-\mathrm{i}$ & $14.6 \mathrm{a}-\mathrm{i}$ & $11.1 \mathrm{~b}-\mathrm{e}$ & $11.2 \mathrm{~b}-\mathrm{e}$ & $8-9$ & $5-7$ & $4-6$ & $4-2$ & $8-6$ & $2-5$ \\
\hline Sturdy $2 \mathrm{~K}$ & $12.1 \mathrm{a}-\mathrm{g}$ & $7.8 \mathrm{a}-\mathrm{e}$ & $13.0 \mathrm{e}-\mathrm{h}$ & $13.7 \mathrm{~g}-\mathrm{i}$ & $5-0$ & $3-6$ & $3-0$ & 0 & $5-7$ & $5-2$ \\
\hline Armor 5110 & $13.8 \mathrm{a}-\mathrm{h}$ & $2.9 \mathrm{a}-\mathrm{c}$ & $13.2 \mathrm{f}-\mathrm{h}$ & $12.5 \mathrm{e}-\mathrm{h}$ & $8-5$ & $4-5$ & $4-5$ & 3 & $7-5$ & $2-5$ \\
\hline LA978UC-36-1-1-B & $10.9 \mathrm{a}-\mathrm{g}$ & $10.3 \mathrm{a}-\mathrm{f}$ & $13.9 \mathrm{hi}$ & $12.6 \mathrm{e}-\mathrm{h}$ & $6-7$ & 5 & $4-6$ & $5-4$ & $6-5$ & $5-3$ \\
\hline Delta Grow 1600 & $11.1 \mathrm{a}-\mathrm{g}$ & $3.5 \mathrm{a}-\mathrm{c}$ & $14.1 \mathrm{hi}$ & $13.8 \mathrm{hi}$ & $7-6$ & $5-6$ & 4 & $4-5$ & $6-5$ & $6-4$ \\
\hline Pat & $17.0 \mathrm{~b}-\mathrm{i}$ & $4.8 \mathrm{a}-\mathrm{c}$ & $11.8 \mathrm{c}-\mathrm{f}$ & $13.1 \mathrm{f}-\mathrm{h}$ & $6-8$ & $6-4$ & $4-5$ & 4 & $7-4$ & $5-2$ \\
\hline Terral TV 8558 & $22.6 \mathrm{e}-\mathrm{i}$ & $8.9 \mathrm{a}-\mathrm{e}$ & $13.5 \mathrm{gh}$ & $12.6 \mathrm{e}-\mathrm{h}$ & $8-7$ & $8-4$ & $6-3$ & $6-5$ & $7-6$ & $5-7$ \\
\hline 26R61 & $0.0 \mathrm{a}$ & $0.9 \mathrm{a}$ & $\ldots$ & $15.8 \mathrm{i}$ & 0 & $0-4$ & 0 & $0-3$ & 0 & $5-2$ \\
\hline
\end{tabular}

${ }^{y}$ Values within this variable followed by the same letter are not significantly different according to a protected least significant difference test for an unbalanced design at $P=0.05 ; \ldots$ indicates that there was no sporulation on any of the inoculated leaves. Least significant difference values were 12.3 to 15.1 for leaf area diseased and 1.4 to 3.0 for latent period, depending on the sample sizes for the pair of means being compared.

${ }^{\mathrm{z}}$ ITs were based on the 0-to-9 scale described by Line and Qayoum (14). Numbers connected by "-" denote a range of ITs, in which the first IT is predominant. 
and other minor genes conferring a slow-rusting type of resistance would be most useful for protecting winter wheat in the eastern United States from stripe rust.

\section{Acknowledgments}

We thank D. Moon, J. Hedge, P. Horevaj, and P. Rohman for technical assistance; and the Arkansas Wheat Promotion Board and the United States Department of Agriculture-Agricultural Research Service for financial support.

\section{Literature Cited}

1. Bariana, H. S., and McIntosh, R. A. 1994. Characterization and origin of rust and powdery mildew resistance genes in VPM1 wheat. Euphytica 76:53-61.

2. Chen, X. M. 2005. Epidemiology and control of stripe rust [Puccinia striiformis f. sp. tritici] on wheat. Can. J. Plant Pathol. 27:314-337.

3. Chen, X. M. 2007. Challenges and solutions for stripe rust control in the United States. Aust. J. Agric. Res. 58:648-655.

4. Chen, X. M., Moore, M., Milus, E. A., Long, D. L., Line, R. F., Marshall, D., and Jackson, L. 2002. Wheat stripe rust epidemics and races of Puccinia striiformis f. sp. tritici in the United States in 2000. Plant Dis. 86:39-46.

5. Hao, Y., Chen, Z., Wang, Y., Bland, D., Buck, J., Brown-Guedira, G., and Johnson, J. 2011. Characterization of a major QTL for adult plant resistance to stripe rust in US soft red winter wheat. Theor. Appl. Genet. DOI 10.1007/s00122-011-1675-8.

6. Helguera, M., Khan, I. A., Kolmer, J., Lijavetzky, D., Zhong-qi, L., and Dubcovsky, J. 2003. PCR assays for the Lr37-Yr17-Sr38 cluster of rust resistance genes and their use to develop isogenic hard red spring wheat lines. Crop Sci. 43:1839-1847.

7. Hovmøller, M. S. 2007. Sources of seedling and adult plant resistance to Puccinia striiformis f. sp. tritici in European wheats. Plant Breed. 126:225233.

8. Hovmøller, M. S., Yahyaoui, A. H., Milus, E. A., and Justesen, A. F. 2008. Rapid global spread of two aggressive strains of a wheat rust fungus. Mol. Ecol. 17:3818-3826.

9. Johnson, R. 1992. Past, present and future opportunities in breeding for disease resistance, with examples from wheat. Euphytica 63:3-22.

10. Lagudah, E. S., Krattinger, S. G., Herrera-Foessel, S., Singh, R. P., HuertaEspino, J., Spielmeyer, W., Brown-Guedira, G., Selter, L. L., and Keller, B. 2009. Gene-specific markers for the wheat gene $\operatorname{Lr} 34 / \mathrm{Yr} 18 / \mathrm{Pm} 38$ which confers resistance to multiple fungal pathogens. Theor. Appl. Genet. 119:889-898

11. Lagudah, E. S., McFadden, H., Singh, R. P., Huerta-Espino, J., Bariana, H. S., and Spielmeyer, W. 2006. Molecular genetic characterization of the Lr34/Yr18 slow rusting resistance gene region in wheat. Theor. Appl. Genet. 114:21-30.

12. Line, R. F. 2002. Stripe rust of wheat and barley in North America: A retrospective historical review. Annu. Rev. Phytopathol. 40:75-118.

13. Line, R. F., and Chen, X. M. 1995. Successes in breeding for and managing durable resistance to wheat rusts. Plant Dis. 79:1254-1255.

14. Line, R. F., and Qayoum A. 1991. Virulence, aggressiveness, evolution, and distribution of races of Puccinia striiformis (the cause of stripe rust of wheat) in North America, 1968-87. U. S. Dep. Agric. Tech. Bull. No. 1788.

15. Luo, Y., and Zeng, S. M. 1995. Simulation studies on epidemics of wheat stripe rust (Puccinia striiformis) on slow-rusting cultivars and analysis of effects of resistance components. Plant Pathol. 44:340-349.

16. Ma, H., and Singh, R. P. 1996. Expression of adult resistance to stripe rust at different growth stages of wheat. Plant Dis. 80:375-379.

17. Markell, S. G., Griffey, C. A., and Milus, E. A. 2009. Inheritance of resistance to stripe rust in three lines of soft red winter wheat. Crop Sci. 49:521528.

18. Markell, S. G., and Milus, E. A. 2008. Emergence of a novel population of Puccinia striiformis f. sp. tritici in eastern United States. Phytopathology 98:632-639.

19. Mateos-Hernandez, M., Singh, R. P., Hulbert, S. H., Bowden, R. L., HuertaEspino, J., Gill, B. S., and Brown-Guedira, G. 2006. Targeted mapping of ESTs linked to the adult plant resistance gene Lr46 in wheat using synteny with rice. Funct. Integr. Genomics 6:122-131.

20. McIntosh, R. A., Wellings, C. R., and Park, R. F. 1995. Wheat Rusts: An Atlas of Resistance Genes. CSIRO, Australia.

21. Milus, E. A., Kristensen, K, and Hovmøller, M. S. 2009. Evidence for increased aggressiveness in a recent widespread strain of Puccinia striiformis f. sp. tritici causing stripe rust of wheat. Phytopathology 99:89-94.

22. Milus, E. A., and Line, R. F. 1986. Number of genes controlling high-temperature, adult-plant resistance to stripe rust in wheat. Phytopathology 76:93-96

23. Milus, E. A., and Markell, S. G. 2008. Intermediate infection types on differential lines cause discrepancies in race identification of Puccinia striiformis f. sp. tritici isolates. (Abstr.) Phytopathology 98:S107.

24. Milus, E. A., Seyran, E., and McNew, R. 2006. Aggressiveness of Puccinia striiformis $\mathrm{f}$. sp. tritici isolates in the south-central United States. Plant Dis. 90:847-852.

25. Park, R. F., and Rees, R. G. 1989. Expression of adult-plant resistance and its effect on the development of Puccinia striiformis f. sp. tritici in some Australian wheat cultivars. Plant Pathol. 38:200-208.

26. Qayoum, A., and Line, R. F. 1985. High-temperature, adult-plant resistance to stripe rust of wheat. Phytopathology 75:1121-1125.

27. Saal, B., and Wricke, G. 1999. Development of simple sequence repeat markers in rye (Secale cereal L.). Genome 42:964-972.

28. Singh, R. P. 1992. Genetic association of leaf rust resistance gene Lr34 with adult plant resistance to stripe rust in bread wheat. Phytopathology 82:835 838

29. Singh, R. P., Huerta-Espino, J., and William, H. M. 2005. Genetics and breeding for durable resistance to leaf and stripe rusts in wheat. Turk. J. Agric. For. 29:121-127.

30. Sthapit, J., and Milus, E. A. 2009. Characterization of adult-plant resistance in soft red winter wheat to stripe rust. (Abstr.) Phytopathology 99:S125

31. William, M., Singh, R. P., Huerta-Espino, J., Ortiz Islas, S., and Hoisington, D. 2003. Molecular marker mapping of leaf rust resistance gene Lr46 and its association with stripe rust resistance gene $\mathrm{Yr} 29$ in wheat. Phytopathology 93:153-159.

32. Zadoks, J. C. 1961. Yellow rust on wheat: studies in epidemiology and physiologic specialization. Tijdschr. Plantenziekten 67:69-256. 